\title{
Leaving Home
}

\section{An Institutional Perspective on Intermediary HQ Relocations}

\author{
Valentino, Alfredo; Schmitt, Jan; Koch, Benno; Nell, Phillip Christopher
}

Document Version

Accepted author manuscript

Published in:

Journal of World Business

DOI:

10.1016/j.jwb.2018.08.004

Publication date:

2019

\section{License}

Unspecified

Citation for published version (APA):

Valentino, A., Schmitt, J., Koch, B., \& Nell, P. C. (2019). Leaving Home: An Institutional Perspective on Intermediary HQ Relocations. Journal of World Business, 54(4), 273-284.

https://doi.org/10.1016/j.jwb.2018.08.004

Link to publication in CBS Research Portal

\section{General rights}

Copyright and moral rights for the publications made accessible in the public portal are retained by the authors and/or other copyright owners and it is a condition of accessing publications that users recognise and abide by the legal requirements associated with these rights.

Take down policy

If you believe that this document breaches copyright please contact us (research.lib@cbs.dk) providing details, and we will remove access to the work immediately and investigate your claim. 


\section{Leaving Home: An Institutional Perspective on Intermediary HQ Relocations}

Alfredo Valentino, Jan Schmitt, Benno Koch, and Phillip Christopher Nell

Journal article (Accepted manuscript)

CITE: Leaving Home : An Institutional Perspective on Intermediary HO Relocations. / Valentino, Alfredo; Schmitt, Jan; Koch, Benno; Nell, Phillip Christopher. In: Journal of World Business, 18.09.2018.

DOl: 10.1016/j.jwb.2018.08.004

Uploaded to CBS Research Portal: January २०1९

(ㄱ २०19. This manuscript version is made available under the CC-BY-NC-ND 4.0 license http://creativecommons.org/licenses/by-nc-nd/4.0/ 


\title{
Leaving Home: An Institutional Perspective on Intermediary HQ Relocations
}

\begin{abstract}
We investigate the effect of changing national institutions on relocations of intermediary HQs. Using a dataset of 154 cross-border relocations between the period from 2000-2015, we draw on the intermediary HQ's middle position within the MNC and investigate how a decrease in institutional quality in the HQ's host country and a change in institutional distance between different MNC units affect the relocation decision. Our findings advance the emergent literature on HQ relocations as well as our knowledge of intermediary HQs and the effect of changing institutions on organizational location choices. Beyond our theoretical contributions, we offer policy and managerial implications.
\end{abstract}

\section{Keywords:}

HQ relocation; intermediary headquarters; institutional quality; ICRG; institutional distance; national governance system.

This work was partially supported by a fund from Erste Bank, Austria [grant number: 11000177]. 


\section{Introduction}

Recently, multinational corporations (MNCs) have started to increasingly unbundle their headquarters (HQ) activities (also referred to as parenting activities, Goold \& Campbell, 1991) and to disperse them geographically (Desai, 2009; Laamanen, Simula, \& Torstila, 2012; Baaij \& Slangen, 2013). Several studies have observed an increase in the cross-border relocations of not only individual activities (Birkinshaw, Braunerhjelm, Holm, \& Terjesen, 2006) but also entire HQs (Benito, Lunnan, \& Tomassen, 2011; Laamanen et al., 2012; Baaij, Mom, Van den Bosch, \& Volberda, 2015). To this end, the "World Investment Report" (UNCTAD, 2003) identified an emerging market for HQs.

Despite these recent advancements, the literature on HQ relocations is still in its infancy compared to the work on the relocation (offshoring) of regular value chain activities (Baaij et al., 2015; Nell, Kappen, \& Laamanen, 2017). Granted, the recent focus on HQ relocations has produced valuable results. For example, firm-specific variables, such as the age or size of HQ units as well as the ownership structure, have been found to affect the likelihood of relocation (Benito et al., 2011; Birkinshaw et al., 2006; Forsgren, Holm, \& Johanson, 1995; Laamanen et al., 2012). Similarly, differences in wages or corporate taxes, proximity to big cities, and agglomeration benefits have been reported to be relevant for location choices (Baaij et al., 2015; Barner-Rasmussen, Piekkari, \& Björkman, 2007; Benito et al., 2011; Birkinshaw et al., 2006; Laamanen et al., 2012). However, while some authors have investigated institutional factors as the potential antecedents of HQ relocation (Birkinshaw et al., 2006; Benito et al., 2011; Laamanen et al., 2012), we still have limited insight into how country institutions and, specifically, institutional change influence HQ relocation decisions.

Furthermore, the previous studies have focused even less on intermediary HQs and how they are affected by institutions and institutional change (Zhou, 2015). This is unsatisfactory as many MNCs operate with multi-layered hierarchies that include intermediary HQs such as regional or divisional HQs in addition to one or more corporate HQs (Nell et al., 2017; Birkinshaw, Ambos, \& Bouquet, 2017). In addition, the scarce evidence seems to indicate that intermediary HQs are more mobile than corporate ones (Laamanen et al., 2012) and that institutional conditions are also relevant 
for their location choice. For example, Starbucks, the American coffee company, moved its European HQ from Amsterdam to London in 2014 (Aglionby \& Houlder, 2014); General Electric, the American multinational conglomerate, relocated its Renewable Energy Business HQ from the US to Paris in 2015 (Rulison, 2015); and, more recently, several MNCs (e.g., EasyJet, LG Electronics or VTB Group) announced that they had already left or planned to leave the UK with their intermediary HQs due to increased institutional uncertainty resulting from Brexit and the potential loss of EU passporting rights (Rodionova, 2016). In this regard, intermediary HQs offer unique insights into the relevance of institutions as their characteristic middle position in-between corporate and local units can be leveraged.

In this paper, we therefore focus on intermediary HQs and how institutions influence the likelihood of their relocation across borders. By using the term intermediary HQ relocation, we refer to the relocation of divisional or regional HQs. We define divisional HQs as entities that are "responsible for a functional activity or for a specific group of units performing similar activities" (Dellestrand, 2011, p. 231), whereas regional HQs are "HQs that administer a firm's regional activities across multiple countries" (Laamanen et al., 2012, pp. 188).

We develop and test hypotheses on the effects of institutional change using a hand-collected dataset of 154 intermediary HQ relocations over a period of 16 years from 2000 to 2015 . To the best of our knowledge, this is the largest dataset on cross-border HQ relocations. We find that a decrease in the institutional quality of the host country of an intermediary HQ increases the likelihood that the HQ will be relocated. Furthermore, we find that the institutional distance between corporate and intermediary HQ location influences the relocation decision. Increasing institutional distance makes the intermediary HQ "stickier". We do not find support for our hypothesis that increasing institutional distance between the intermediary HQ and the local subsidiaries increase the likelihood of relocation.

Our study contributes in a number of ways. First, the focus on national institutions and institutional distance advances our understanding of the HQ relocation phenomenon (Laamanen et al., 2012; Birkinshaw et al., 2006; Barner-Rasmussen et al., 2007; Benito et al., 2011). We provide 
additional, complementary explanations of why HQ relocations occur. We show how intermediary HQs are sensitive to the institutional changes of host countries as well as to changes in the institutional distance between host- and home countries. While new to the HQ relocation literature, our findings also extend, on a more general level, the work on offshoring of high-value-adding functions such as R\&D (Bertrand \& Mol, 2013; Lewin, Massini, \& Peeters, 2009; Demirbag \& Glaister, 2010).

Second, we contribute to the literature that links institutional theory to governance choices (Bevan, Estrin, \& Meyer, 2004; Brouthers, 2002; Meyer, Estrin, Bhaumik, \& Peng, 2009; Driffield, Mickiewicz, \& Temouri, 2016; Meyer \& Peng, 2005). We demonstrate that change in national institutional systems affects firm strategic choices such as HQ relocations. We argue that this occurs because institutional change influences an HQs' ability to draw on its ownership advantages. To this end, institutional change is a relevant factor both in terms of changing host country conditions and changing distances between the home- (corporate HQ location) and host country of the intermediary HQ.

Third, we contribute to the literature on HQ-subsidiary relationships within MNCs. Those studies "have largely focused on the MNC headquarters-subsidiary dyads and overlooked the intermediary supervisory units" (Zhou, 2015, p. 280). In this paper, we go beyond the motherdaughter structure of MNCs (Kogut \& Zander, 1995) and shed more light on the internal complexity of HQ systems and the role played by intermediary HQs. We show that MNCs consider a multitude of factors when relocating intermediary HQs. They specifically consider the evolution of institutional distance between the locations of their corporate HQs and their intermediary HQs.

This paper also offers policy and managerial implications. Our results empirically support the idea that institutional quality and its dynamics have a significant effect on relocation decisions. Thus, national institutions and their (relative) development are relevant in attracting and retaining HQs. Policy makers may want to continuously improve the quality of their country institutions and monitor those of competing locations. MNC managers are advised to not only consider cost factors (such as taxation) but also the institutional setup and its dynamics when deciding about HQ relocation. On a 
more general level, MNC managers might profit from our empirical support for the idea that intermediate HQs have indeed become quite mobile and that a number of firms try to benefit from relocation, which might spur more relocations in the future.

\section{Literature Background}

\section{Institutions}

"Institutions are the humanly devised constraints that structure political, economic and social interactions" (North, 1991, p.97). They consist of formal rules (such as laws and property rights) as well as informal norms of behaviour (e.g., cultural values). These rules vary across countries, and they are therefore of substantial importance for internationalizing firms and multinational corporations. In this study, we focus on formal institutions.

Formal institutions define the "rules of the game" and influence the transaction and production costs of firms. For example, high quality institutions help firms grow and develop (Thomas, 2009; Zhou, 2015). Countries with high quality institutions (i.e., a legal system that is transparent, impartial, and effective; public institutions that are honest as well as credible; and policies that support competition and openness to international trade) can be characterized by lower levels of uncertainty for economic activities, as the business environment is easier to decipher (Zhang, Zhou, \& Ebbers, 2011). In addition, efficient judicial systems increase the incentive for firms to invest in research and development as their innovations are better protected (Kumar, Rajan, \& Zingales, 2001), and welldeveloped financial markets support firms with financial resources. As a consequence, formal institutions co-determine the feasibility and profitability of doing business in a certain country (North, 1991).

Many international business scholars have therefore investigated the effects of institutional quality, for example, on MNC location and governance decisions for their international affiliates (Alvarez \& Marin, 2010; Globerman \& Shapiro, 2003; Hernandez \& Nieto, 2015; Kwok \& Tadesse, 2006). For instance, there is evidence that MNCs to some extent avoid institutionally weak contexts 
(Holmes, Miller, Hitt, \& Salmador, 2013) ${ }^{1}$. Firms also pick ownership modes that help safeguard against some institutional risks (Slangen \& van Tulder, 2009), or they staff foreign affiliates with expatriates or third-country nationals to keep corruption at bay (Muellner, Klopf, \& Nell, 2017).

Collectively, the previous research has made good progress in understanding national corporate governance systems and institutions and their influence on MNC affiliates. However, the previous work has focused less on how national institutions affect organizational units higher in firm hierarchies such as corporate or intermediary HQs.

\section{MNC structures}

MNC organizations have traditionally been described as mother-daughter structures (Kogut \& Zander, 1995), and there is a substantial body of work on "headquarters-subsidiary relationships" (Bartlett \& Ghoshal, 1989). Only recently has there been greater emphasis on intermediary units in the hierarchy of MNCs such as divisional or regional HQs (e.g., Lehrer \& Asakawa, 1999; Enright, 2005; Schotter, Mudambi, Doz, \& Gaur, 2017; Hoenen, Nell, \& Ambos, 2014; Mahnke, Ambos, Nell, \& Hobdari, 2012; Zhou, 2015) $)^{2}$

Focusing on intermediary HQs acknowledges that MNCs often operate with multilayer hierarchical organizations. In MNCs, corporate HQ managers and corporate-level units (such as corporate staff) are exposed to high degrees of diversity and complexity in the MNC network (Wolf $\&$ Egelhoff, 2002). The limited cognitive ability and attention of corporate level staff (Bouquet \& Birkinshaw, 2008) mean that tasks of control and supervision are frequently delegated to intermediary units when MNCs grow (Verbeke \& Kenworthy, 2008). These intermediary hierarchical units then take over some parenting tasks from the corporate HQs and they become "de facto" parents for frontline subsidiaries (Goold \& Campbell, 2002; Beugelsdijk, Nell, \& Ambos, 2017).

\footnotetext{
${ }^{1}$ Of course, they do not shun such destinations entirely because many arbitrage opportunities (e.g., lower labor costs) correlate with weaker institutional contexts.

${ }^{2}$ There is related work on „middle management“, for example by Wooldridge and Floyd (1990; 1992). However, this work usually does not consider formal institutions and is rather oriented towards managerial questions.
} 
Intermediary HQs are thus "hybrid" units (Lehrer \& Asakawa, 1999) that play a double role within MNCs: they are agents for corporate HQs and parents for the operational subsidiaries under their responsibility. They help with information processing between frontline subsidiaries and corporate HQs (Nell, Ambos, \& Schlegelmilch, 2011; Zhou, 2015), and they can also be understood as two-way channels of communication or brokers that are related to the $\mathrm{MNC}$ as a whole and to the subsidiary environment (Hoenen et al., 2014). They translate corporate strategies and goals into local ones (Forsgren et al., 1995; Chakravarty, Hsieh, Schotter, \& Beamish, 2017), and they help promote and leverage local strategic initiatives within the MNC network (Birkinshaw \& Hood, 1998).

Furthermore, they dispose of the specific decision rights that are allocated to them by the corporate HQs (Mahnke et al., 2012; Piekkari, Nell, \& Ghauri, 2010; Lunnan \& Zhao, 2014; Kähäri. Saittakari, Piekkari, \& Barner-Rasmussen, 2017). For example, divisional HQs usually have decision rights for a certain product range, regional HQs for a range of geographic markets (Wolf \& Egelhoff, 2002). With this formal authority, intermediary HQs set priorities in case of uncertainty among affiliates (Hart \& Moore, 2005), solve conflicts (and avoid the escalation of conflict to higher hierarchical levels) (Poppo, 2003; Decreton, Dellestrand, Kappen, \& Nell, 2017; Decreton, Nell, \& Stea, 2018), perform input and output control tasks on behalf of the corporate HQs (Kostova, Nell, \& Hoenen, 2016), and help coordinate the interdependent activities of the affiliates for which they are responsible (Nell et al., 2011).

The research on intermediary HQs has made great progress. However, while there has been some emphasis on the initial location choice for such units (e.g., Belderbos, Du, \& Goerzen, 2017), much less work has been done on the relocation of existing units. In this paper, we particularly focus on the relocation of intermediary HQs. The scarce evidence on intermediary HQ relocations show that, while corporate HQs are quite sticky (Meyer \& Benito, 2016), intermediary HQs are relatively mobile (Laamanen et al., 2012; Benito et al., 2011).

Unit-specific (e.g., the HQ's size) and MNC-level characteristics (e.g., the degree of internationality) seem to influence the relocation likelihood of intermediary HQs (Birkinshaw et al., 
2006; Benito et al., 2011; Laamanen et al., 2012). However, few studies have investigated countryspecific variables such as national governance systems and institutions (Baaij et al., 2015; BarnerRasmussen et al., 2007; Benito et al., 2011; Birkinshaw et al., 2006; Laamanen et al., 2012). Using the term "supervisory units" for what we call intermediary HQs, Zhou (2015, p. 280) summarizes that "the literature missed the most unique dimension of MNC structure: the allocation of formal supervisory responsibilities across national borders".

Therefore, we develop how change in the national institutional context of an intermediary HQ unit affects the likelihood of its relocation. We thereby leverage the unique position of an intermediary HQ within the hierarchy of the MNC and differentiate between institutional change in the location of intermediary HQs, increasing institutional distance between the corporate and the intermediary HQ, as well as increasing institutional distance between the intermediary HQ and the affiliates for which the intermediary HQ is responsible. We particularly focus on institutional change. In fact, formal institutions do evolve, sometimes abruptly, shaping economic growth or decline (North, 1991). These changes can more quickly influence managerial decisions compared to informal institutions, which generally change at a slower pace (Estrin, Baghdasaryan, \& Meyer, 2009).

\section{Hypothesis Development}

Headquarters such as corporate and intermediary HQs must perform their parenting tasks effectively and efficiently (Nell \& Ambos, 2013). It has been argued that MNCs frequently allocate supervisory and coordination responsibilities (and thus intermediary HQs) to countries with relatively good institutions (Globerman \& Shapiro, 2003; Zhou, 2015). For example, when Procter \& Gamble was searching for the right location for its Global Business Services HQ in 2001, it chose Costa Rica due to its high quality institutions compared to alternative locations such as Mexico (Luxner, 2001; Zhou, 2015). There are several reasons for such behaviour.

The first important aspects are the availability of information and information processing capabilities of the intermediary HQ both of which are influenced by national institutions (Ali \& Crain, 
2001). Intermediary HQs must make decisions regarding priorities, conflicts, or coordination on behalf of the subsidiaries for which they are responsible. Therefore, they try to make sense of and synthesize high quality and timely information about many business-related factors. Most of this information comes through internal channels from the dispersed subsidiaries, which specialize in local information seeking (Cantwell \& Santangelo, 1999). However, information stemming from the intermediary HQ country can be a valuable complement (Zhou, 2015). After all, it is the unique advantage of MNCs compared to domestic firms that they can complement local information with information from other parts of their network (Meyer, Mudambi, \& Narula, 2011). Countries with high quality institutions are usually characterized by a higher availability of such information from the public sector (e.g., consumption or inflation data), other firms (e.g., marketing research), or universities (e.g., economic outlooks). Those countries provide more sophisticated markets for knowledge, prediction, and interpretation, they possess clearer disclosure regimes, and they suffer from fewer censorship issues (Fiaschi, Giuliani, \& Nieri, 2017; North, 1990; Zhou, 2015). Furthermore, high quality national education systems allow intermediary HQs to recruit staff that are well-trained in collecting and interpreting information, and such HQ staff are more willing to take on jobs in locations with high quality institutions (Collings, Morley, \& Gunnigle, 2008). Similar to the offshoring of other higher-value-adding activities (Contractor, Kumar, Kundu, \& Pedersen, 2010; Demirbag \& Glaister, 2010; Lewin et al., 2009; Manning, Massini, \& Lewin, 2008), intermediary HQs also require locations with a good knowledge infrastructure and access to expertise and qualified employees.

Second, the institutional quality of a country smoothens the process of running HQs. In highquality locations, there is an ample supply of complementary service suppliers such as accountants and consultants. Furthermore, institutions reduce uncertainty for intermediary HQs. High-quality institutions are characterized by lower levels of regulatory unpredictability (Demirbag \& Glaister, 2010; Hernandez \& Nieto, 2015) and a lower risk that the local government will establish unfavourable policies towards foreign-owned firms (Rodriguez, Uhlenbruck, \& Eden, 2005; Slangen 
\& van Tulder, 2009). After all, intermediary HQs are also often foreign-owned subsidiaries that suffer from the liability of foreignness. High-quality institutions reduce some of these liabilities. For example, good control of corruption and few obstacles to foreign-owned businesses reduce problems for intermediary HQs. In addition, property rights influence ownership and control rights (North, 1990; Zhou, 2015). When property rights regimes are faulty and arbitrary, intermediary HQs must engage in many difficult interactions with different institutional actors increasing transaction costs.

In sum, intermediary units placed in high quality contexts should be better able to possess, interpret, and synthesize local information, to employ and retain appropriate staff, and to operate smoothly at low transaction- and coordination costs due to lower levels of uncertainty and formal institutional hazards. When the intermediary HQ country's institutional quality decreases, the abovedescribed inefficiencies and challenges are realized. In fact, formal institutions can change in unfavourable ways quite quickly. Recent examples include the United Kingdom (e.g., Brexit-related uncertainty), Turkey, or Poland. In turn, a decrease in institutional quality leads to a search process during which the MNC evaluates potential alternative locations that offer better conditions for intermediary HQs. For example, the British Airline Company EasyJet relocated its European HQ from the UK to Austria after discussions around Brexit (Topham \& Sweney, 2017). With the risk of the UK leaving the EU, EasyJet faced high legal uncertainty and would potentially no longer be able to operate flights between two EU countries. Therefore, we propose the following:

Hypothesis 1: The stronger the decrease in institutional quality in the host country where the intermediary $H Q$ is located, the higher the likelihood that the $M N C$ will relocate the intermediary $H Q$ to another country.

MNCs are spatially dispersed organizations. By establishing value-creating and corporate activities abroad, they work in different institutional, political, and legal environments, and they interact with different institutions. This geographical dispersion exacerbates the need of MNCs to manage the distance between corporate HQs and subsidiaries with the aim of reducing inefficiencies (Ghemawat, 
2001; Kogut \& Zander, 1992; Zaheer, 1995). Distance can be defined as "the difference between two countries with regard to a particular aspect of social context, such as cultural, administrative, economic, linguistic, or institutional" (Kostova et al., 2016, p.13).

Distance creates major challenges for MNCs, for example, when they attempt to transfer knowledge, to manage joint ventures abroad, or to achieve legitimacy in a foreign country (Ambos \& Ambos, 2009; Kostova \& Zaheer, 1999; Xu \& Shenkar, 2002). We focus on institutional distance, which reflects the differences in the institutional setups between two locations. We propose that growing institutional differences over time affect the likelihood that the intermediary HQ will be relocated. Due to its intermediary position, there are two relevant types of institutional distance: (1) the differences between the corporate HQ and the intermediary HQ location, and (2) the differences between the intermediary HQ location and the locations of the subsidiaries for which the intermediary HQ is responsible. We start with the latter.

We argue that increasing institutional distance between the locations of the intermediary HQ and the local subsidiaries makes a relocation of the intermediary HQ more likely. Growing institutional differences reduce the ability of the intermediary HQ to fulfil a value-adding parenting role for its subsidiaries (Beugelsdijk et al., 2017). First, larger institutional differences are usually associated with higher communication and coordination challenges. For example, growing differences in the legal system, the rule of law, and important bureaucratic principles and regulations require more adaptation of processes and accompanying documents such as reports.

Second, growing contextual differences also increase the likelihood of conflicts and misunderstandings. For example, Kostova et al. (2016, p. 14) argued that subsidiaries "from institutionally distant countries are likely to possess and use different information, operate out of different cognitive frames and heuristics, and, as a result, have difficulties understanding and interpreting HQ' priorities and requests. This challenges the subsidiary's correct understanding and interpretation of $H Q$ ' objectives and requests". Similarly, due to increasing differences, the correct interpretation of information from local subsidiaries becomes more difficult on the level of the HQ. 
Thus, miscommunication and mutual misinterpretation is likely to reduce the value-added of intermediary HQs as the HQs' unfamiliarity with the local subsidiary context increases (Dellestrand \& Kappen, 2012; Beugelsdijk et al., 2017). In such situations, it is more arduous for intermediary HQs to aggregate, evaluate, and synthesize information from local subsidiaries and to decide on how and in which way corporate strategies and tactics shall be adapted.

Finally, growing differences make it more likely that the intermediary HQ makes inappropriate decisions related to the prioritization of tasks or conflicts resulting in detrimental effects on the subsidiaries (Brenner \& Ambos, 2013; Suchman, 1995). For example, Holm, Decreton, Nell, \& Klopf (2017) report how HQs misinterpret the subsidiary's local institutional context, which leads to costly and lengthy response processes on the level of the subsidiary. Growing differences might also create confusion on how to proceed and will, consequently, lead to inertia in strategic decision processes (Zhou, 2015).

In sum, increasing institutional distance between intermediary HQs and subsidiaries leads to increasing coordination, control challenges and costs. Under such circumstances, the intermediary HQ adds less value and loses justification for its existence. In turn, this increases the pressure to modify the intermediary HQ's organizational setup or location. Relocating local subsidiaries (instead of the intermediary HQ) is not a valid option. The local subsidiaries are located in countries for specific reasons (e.g., market-, resource-, or efficiency-seeking motives) other than the institutional closeness to the HQ (Dunning, 1981). Therefore, we propose the following:

Hypothesis 2: The stronger the increase of institutional distance between the host country of the intermediary HQ and the host countries of the local subsidiaries, the higher the likelihood that the MNC will relocate the intermediary $H Q$ to another country.

We argue that the likelihood of relocation is also influenced by the institutional distance between the intermediary HQ and the corporate HQ. In fact, most of the reasoning from Hypothesis 2 is similar. Growing contextual differences between the two HQs make it more difficult for the corporate HQ to 
fulfil its parenting role for the intermediary $\mathrm{HQ}$, there are likely to be more conflicts and misunderstandings between the two HQs, and coordination costs as well as adaptation costs are likely to increase. Since corporate HQs are quite sticky in general (and responsible for other regions and divisions that might pull in other directions), the relocation pressure is on the intermediary HQ.

However, an intermediary HQ is not simply a subsidiary of the corporate HQ, it is also the de facto parent for the subsidiaries in its region or division (Nell \& Ambos, 2013). To this end, the intermediary HQ exists only if it can perform the value-adding role for frontline subsidiaries better than the corporate HQ or if it substantially alleviates the corporate HQ from administrative and entrepreneurial tasks.

In the ideal scenario, the unique position of the intermediary HQ in-between frontline subsidiaries and corporate $\mathrm{HQ}$ enables the $\mathrm{MNC}$ to profit from region- or division-specific information (Lehrer \& Asakawa, 1999) and to provide a unique perspective and interpretation based on the sensemaking that is performed by the intermediary HQ (Alfoldi, Clegg, \& McGaughey, 2017). As a consequence, to perform their role well, intermediary HQs should possess and use information as well as cognitive schemes and heuristics that are different from those used by other units, particularly corporate HQs.

Converging institutional setups between the corporate and the intermediary HQ locations calls into question the intermediary HQ's raison d'être. If cognitive frames and heuristics are very similar, as well as the formal rules of the game, then the corporate HQ could relatively easily take over the parenting tasks itself. Thus, all else being equal, we would expect that increasing institutional distance between the intermediary HQ and the corporate HQ location decreases the likelihood of intermediary HQ relocation.

Hypothesis 3: The stronger the increase of institutional distance between the host country of the intermediary $H Q$ and the home country (i.e., the location of the corporate $H Q$ ), the lower the likelihood that MNCs will relocate the intermediary $H Q$ to another country. 


\section{Data and Methods}

\section{Data and Sample}

Our analysis focuses on intermediary HQ relocations. Thus, any movements of corporate HQs, local subsidiaries or other facilities (e.g., R\&D centres) are excluded. We define relocations as the processes through which a firm moves its intermediary HQ from one country to another and the HQ unit maintains "a degree of continuity in identity" (Laamanen et al., 2012, p. 195). Hence, the relocation implies the transfer of the top management team as well as HQ functions. Inversions, i.e., relocations that exclusively involve the legal seat of the HQ (Slangen, Baaij, \& Valboni, 2017), as well as first establishment of HQs (e.g., if a US firm decides to establish its regional HQ in Europe for the first time and vice versa) are excluded.

We focus on Europe-related relocations, i.e., we considered three types of relocation: (1) relocation within Europe (e.g., from Germany to Austria), (2) from Europe to any other non-European country (e.g., from Switzerland to Singapore), and (3) from any other non-European country to Europe (e.g., from the US to the UK). However, we excluded the latest members of the EU (Bulgaria and Romania) because of the lower availability of high-quality information in those countries.

The hypotheses are tested on a hand-collected multi-country sample of relocations. We started by identifying the population of all intermediary HQs in 27 European countries (EU-25 plus Norway and Switzerland) during a 16-year period from 2000 to 2015 in the Orbis database, which contains extensive financial and ownership information. Since relocation events are relatively rare and concentrated in larger companies with international operations (Laamanen et al., 2012; Benito et al., 2011), we first retrieved the top quintile of all MNCs in Europe according to turnover in the Orbis database from 2000 to 2015 . We then used the Orbis data on financial reporting and ownership as well as on legal entity names (e.g., "Henkel Central Eastern Europe") to clearly distinguish intermediary HQs from frontline subsidiaries. We cross-checked these data with annual reports where available. With this approach, we arrived at a total sample of 3,467 intermediary HQs. 
As a second step, we followed Laamanen et al. (2012) and identified HQ relocations on the basis of the news database "LexisNexis". For each intermediary HQ in our sample, we collected all news and newspaper articles in LexisNexis over the entire time period in three languages (English, Italian, and German). We carefully checked all articles for announced or realized HQ relocations. We paid attention to the issue of potential false positives in the sampling by going through another news database called "Factiva" and through several other sources of information, i.e., stock market notifications, local business press, and Google news. Our extensive research in the abovementioned data sources also helped us in reducing the problem of potential false negatives. However, we are aware that the sample presumably does not include all relevant relocation events. It considers only relocations from larger companies that are important enough to be mentioned by those documents and news that we processed. Nevertheless, the covered documents come from a wide range of sources and have been searched in multiple languages, and our sample is considerably larger than those of previous studies (for example, Laamanen et al. (2012) covered only 52 relocations). Following this sampling procedure, we identified 154 relocations of intermediary HQs ${ }^{3}$.

\section{Measures}

The dependent variable is the decision to relocate an intermediary HQ across countries. In line with Laamanen et al. (2012), the dependent variable is measured as a dichotomous variable, which takes the value 1 for relocation and 0 otherwise.

The first independent variable is the absolute decrease in institutional quality of the intermediary HQ location. We use the International Country Risk Guide (ICRG) measures, and following Bekaert, Harvey, Lundblad, \& Siegel (2014), we measure institutional quality through the components 'Law and Order' (scale from 0 to 6), 'Bureaucracy Quality’ (scale from 0 to 4), and 'Corruption' (scale from 0 to 6). Higher values in the dimensions correspond to better country

\footnotetext{
${ }^{3}$ We also found five multiple relocations, i.e., when the same firm relocates the same HQ unit more than once. We kept those observations in the dataset.
} 
performance. Those measures are particularly suitable to our study as they are forward-looking based on the assessment of executives and proved to be predictive of risk realizations (Bekaert et al., 2014). We measure the three components individually on the intermediary HQ country-level and apply a factor analysis. Depending on the number of lagged years (e.g., one year before the observation of a relocation, three years before observation, etc.), we obtain different factor loadings for our individual measures; however, all factor loading are above 0.8 and produce a single construct with a Cronbach $\alpha>0.7$. We capture the change in institutional quality over a three-year period (i.e., one year before relocation compared to three years before relocation) and log-transform the absolute values of the decreases in institutional quality. Increases in institutional quality were set to 0 to test the hypothesized directionality (H1). Robustness tests were done with a change variable over a 5-year period.

The second independent variable is the measure of distance. We operationalize this variable through the increase in institutional distance from the intermediary HQ to the subsidiaries (H2) and to the corporate HQ (H3). Consistent with the operationalization of H1, we again draw on the ICRG indicators and measure the institutional quality of the subsidiary and corporate HQ countries. For the former, we create the weighted average of institutional quality for the subsidiaries under the control of the intermediary HQ. The weight corresponds to the number of subsidiaries that are located in each country. We create the measure of institutional distance by subtracting the average institutional quality of the subsidiary countries from the intermediary HQ country and the institutional quality of the intermediary HQ country from the corporate HQ country. The change in institutional distance is again measured over a three-year period (i.e., one year before relocation compared to three years before relocation), and we log-transform all increases in institutional distance. Decreases in institutional distance were set to 0 to test the hypothesized directionality ( $\mathrm{H} 2$ and $\mathrm{H} 3$ ).

To control for alternative explanations, we included a wide range of controls. On the intermediary HQ country-level, we include the absolute level of institutional quality one year before the relocation, as previous studies (e.g., Zhou, 2015) have shown that intermediary HQs are more 
likely to be located in countries with high institutional quality. Additionally, we control for corporate tax and employment rates, which are measured as the log-transformed rates one year before the relocation. The variable GDP per capita is measured in log-transformed US Dollar (2010 PPPs) one year prior to relocation and reflects the overall development level of a country.

At the level of the MNC, we control for the overall MNC size measured as the log-transformed number of employees, as larger MNCs might relocate intermediary HQs more often. Furthermore, as shown in the previous studies, a possible alternative explanation for HQ relocations is related to the degree of internationalization of the MNC. It is measured as the ratio between the amount of exports and the total amount of revenues generated by the firm (Sullivan, 1994). Moreover, since the relocation decision could be a consequence of $M \& A$ operations, we create a control variable $(M \& A$ Activity) for that. We also control for the ownership concentration of the MNC. It is measured as the percentage of voting shares held by shareholders. We identify two main categories: concentrated ownership, where one shareholder owns more than $20 \%$ of the total shares (given the value of 1); and dispersed ownership, where no single shareholder holds more than $20 \%$ of the total shares (value of 0). Lastly, we control for the industry. We use the SIC system's first digit of the code. We merged industries ' 8 ' and ' 9 ' due to the limited number of observations in those industries.

At the HQ-level, we control for the $H Q$ size which can be an indicator for the number of performed parent activities and the importance of the unit within the MNC. It is measured as the logtransformed number of employees. In addition, we control for the different types of intermediary $H Q s$. They can either take over a regional responsibility as a regional HQ or a product- or functionrelated responsibility as a divisional HQ. The variable takes the value 1 for regional HQs and 0 for divisional HQs. We also control for imitative behaviour by other MNCs. We use the operationalization of Laamanen et al. (2012, p. 200) for this trend variable counting "the number of relocation events in the year prior to the firm-year observation". Finally, we control for geographic distance between the intermediary HQ and the corporate HQ as well as the subsidiaries. For the intermediary HQ - corporate HQ distance, we take the simple log-transformed geographic distance 
measure as compiled by Berry, Guillén, \& Zhou (2010). For the intermediary HQ - subsidiary distance, we follow Laamanen et al. (2012) and calculate the geographical distance as the sum of logarithms of geographical distances between the country of the intermediary HQ and the countries of each subsidiary. We then divide the result by the number of subsidiaries.

\section{Descriptive Statistics}

In line with Laamanen et al. (2012), the highest relocation activity occurs in Central and Western Europe: Switzerland is one of the most attractive European countries for HQ units, gaining 44 HQs between 2000 and 2015, while losing only 11 in the same period of time. The UK, however, gained 24 HQ units but also lost 37 HQs. Similarly, the Netherlands and France lost 12 and 10 HQs, respectively, over the observed 16 years. Germany and Austria show a relatively high activity with no clear direction and only a small net loss of HQs ( -5 and -1 , respectively). For the remaining European countries, the flow is comparably small, and HQ inflows approximately equal HQ outflows. We also identify 12 relocations of HQs shifting from non-European countries to Europe and 19 relocations from Europe to non-European countries. A total of 55\% of all relocations occur in the manufacturing sector, $20 \%$ in the service sector, $15 \%$ in trade, and $10 \%$ in the finance sector.

Table 1 shows the correlation matrix. The dataset does not suffer from severe multicollinearity issues. The variance inflation factors (VIF) are below the critical threshold of 10 for all variables (O’Brien, 2007). The tolerance does not fall below 0.1 (Hair, Black, Babin, Anderson, \& Tatham, 2006).

\section{$<<$ Table 1 about here >>}

Table 2 reports the definitions and descriptive statistics for the variables used, and Table 3 compares the variable means for the non-relocated units and the relocated units. Based on univariate tests, we observe that relocating HQs belong to larger MNCs that are more international and that rather have dispersed ownership. Furthermore, relocating HQs are more likely to be RHQs and are 
larger in terms of employees compared to non-relocating HQs. To this end, our data seems to reproduce patterns that have been previously observed (e.g., Laamanen et al., 2012; Birkinshaw et al., 2006; Benito et al., 2011). Finally, we find that relocating HQs are geographically and institutionally more distant from both their supervised subsidiaries and their CHQ.

Table 4 reports descriptive statistics on the relocated HQs before and after the relocation. HQs decrease their number of employees through the relocation and move to countries with lower corporate tax rates, lower employment rates, and higher GDP per capita. Again, these findings are in line with the previous research (e.g., Laamanen et al., 2012; Birkinshaw et al., 2006; Benito et al., 2011). Additionally, we find that HQs move to countries with almost similar, but more stable institutional quality. Those target countries are geographically as well as institutionally closer to the supervised subsidiary countries; in contrast, they are geographically more distant, but institutionally closer to the MNCs' home country.

<<Table 2, Table 3, Table 4 about here >>

\section{Estimation}

We run logistic regressions with 3,467 observations to analyse the determinants of the decision to relocate an HQ unit:

$$
y_{n}=\alpha x_{n}+\beta r_{n}+\varepsilon_{n}
$$

where $\mathrm{y}_{\mathrm{n}}$ is the company's observed decision to relocate, $\mathrm{x}_{\mathrm{n}}$ is a vector of the variables related to our three hypotheses on institutional quality and institutional distance, and $r_{n}$ is a vector of control variables. The probability that $\mathrm{y}_{\mathrm{n}}$ is equal to 1 is the result of the following formula:

$$
P\left(y_{n}=1 \mid x_{n}\right)=\frac{\exp \left(x_{n} \alpha+z_{n} \beta\right)}{1+\exp \left(x_{n} \alpha+z_{n} \beta\right)}
$$

We will report on several robustness estimations further on. 


\section{Results}

The results of the logistic regression models are presented as follows. Specification 1 (Table 5, Model

1) contains only control variables; Specification 2 (Table 5, Model 2) contains the full model; Specifications 3 and 4 (Table 5, Models 3 and 4) contain robustness checks.

\section{$<<$ Table 5 about here $>>$}

In our discussion of the results, we focus on the full model (Table 5, Model 2). In Hypothesis 1, we predict that a decrease in institutional quality in the host country where the intermediary HQ is located increases the likelihood of HQ relocation. We find support for $\mathrm{H} 1$ at $\mathrm{p}<5 \%$. The effect is stable across our robustness tests.

In Hypothesis 2, we investigate the effect of institutional distance between the host country of the intermediary HQ and the host countries of the local subsidiaries on the likelihood that the MNC will relocate the intermediary HQ to another country. Specifically, we suggest that an increase in institutional distance increases the likelihood of HQ relocation. While the coefficient is positive, the effect is consistently insignificant across the various specifications. Therefore, $\mathrm{H} 2$ is not supported.

In Hypothesis 3, we investigate the effect of institutional distance between the host country of the intermediary HQ and the home country of the corporate HQ on the likelihood that the MNC will relocate the intermediary HQ to another country. Contrary to $\mathrm{H} 2$, we expect that an increase in institutional distance decreases the likelihood of HQ relocation. We find a negative effect that is highly significant at the $5 \%$ confidence level. Hence, H3 is supported.

The control variables produce the following results. On the level of the host country of the intermediary HQ, we find that a higher employment rate and a higher GDP per capita increase the likelihood of HQ relocation. On the MNC parent-level, the analysis suggests that larger MNCs with dispersed ownership and no recent M\&A activities are more likely to relocate their intermediary HQs. 
On the HQ-level, we find that smaller HQs with a high geographical distance to their corporate HQs and their subsidiaries are more likely to be relocated.

We conducted several robustness checks. First, we used robust-cluster and robust year-cluster standard errors for our estimations. The results of the models are consistent, with similar coefficients and significances (see Table 5, Models 3-4). Second, we used different time horizons to measure our institutional change variables. While our main model (Table 5, Model 2) was based on changes over three years before relocation, we ran robustness tests by using the last five years before relocation. Again, the results are qualitatively identical. Third, we changed the specification of our institutional quality measure. We used the non-logged versions in one set of robustness tests, and, in another set, we followed previous IB studies that used only the level of corruption as a proxy of institutional quality (Cuervo-Cazurra, 2006; Zhao, Kim, \& Du, 2003). For the latter test, we used ICRG's corruption indicator. Our main results are again supported.

\section{Discussion}

The aim of this paper is to analyse the role of change in national institutions and institutional distance as the antecedents of the decision to relocate intermediary HQs. We show that a decrease in the institutional quality of the intermediary HQ's host country increases the likelihood of the intermediary HQ relocation, whereas an increase in institutional distance between the intermediary HQ's host country and the corporate HQ's home country reduces the likelihood that the MNC will relocate the intermediary HQs to another country. Contrary to our expectations, an increase in institutional distance between the intermediary HQ's host country and the countries of its supervised subunits does not affect the likelihood of relocation. These insights allow us to contribute to the literature in three ways.

First, we advance the emerging stream of literature on HQ relocations. The previous studies on HQ relocations have focused predominantly on firm-specific variables, such as the degree of internationalization, the size of HQ units, and the concentration of ownership, or on country-specific 
variables, such as differences in wages or corporate tax levels, without considering possible alternative explanations. To fill this gap, some scholars have begun to speculate on institutional factors as potential antecedents of HQ relocations (Birkinshaw et al., 2006; Benito et al., 2011; Laamanen et al., 2012). These previous studies have mainly built on insights from organizational institutionalism (Di Maggio \& Powell, 1983; Meyer \& Rowan, 1977) and emphasized how MNCs may seek to establish or maintain institutional legitimacy by imitating competitors or following main stakeholders. However, they do not show conclusive results about the relationship between institutions and the HQ relocation decision. To the best of our knowledge, there is no study that explores the effects of changing institutional characteristics and distances on the decision to relocate intermediary HQs. This study advances our knowledge on the impact of institutions and their quality on MNC decisions to relocate their intermediary HQs. Intermediary HQs are sensitive to their host country's institutional quality and seek to minimize costs and formal institutional hazards. Our results confirm the previous studies that underscore how "good institutional governance" is a crucial precondition for firm development (Chan \& Makino, 2007; Rodriguez et al., 2005; Slangen \& van Tulder, 2009). Being units of foreign-owned firms, they move away from local governments that establish unfavourable policies towards them in unpredictable ways (Rodriguez et al., 2005; Slangen \& van Tulder, 2009). Weak institutions as well as high levels of uncertainty, corruption, and bureaucracy hinder HQs in creating parenting advantage. While new to the HQ relocation literature, our findings also extend, on a more general level, the work on offshoring of high-value-adding functions such as R\&D (Bertrand \& Mol, 2013; Lewin et al., 2009; Demirbag \& Glaister, 2010).

Second, we contribute to the literature that links institutional theory to governance choices. Although international business scholars know that "institutions matter", they still do not know how they effectively matter (Jackson \& Deeg, 2008). While there is much research that investigates how the overall level of institutional quality affects firm decisions (e.g., Zhou, 2015; Holmes et al., 2013; Alvarez \& Marin, 2010; Globerman \& Shapiro, 2003), our knowledge on the effect of institutional dynamics and institutional change on firm decisions is limited (Carney, Estrin, Liang, \& Shapiro, 
2018). Some notable exceptions are the studies of Kafouros and Aliyev (2016) and Driffield et al. (2016) who investigate how institutional change affects firm performance or firm ownership. We extend this research by analysing how institutional change affects the relocation decision of intermediary HQs. Our findings provide empirical support for the argument that some institutional setups provide better support for ownership advantages than others (Carney et al., 2018). The main tasks and abilities of intermediary HQs include the information processing between subsidiaries and corporate HQs (Zhou, 2015), developing local strategic initiatives (Birkinshaw \& Hood, 1998), and coordinating the interdependent activities of their supervised subsidiaries (Nell et al., 2011). A decreasing level of institutional quality makes it difficult for intermediary HQs to fulfil such roles and create a parenting advantage. As an answer to the institutional dynamism in the host location, the MNC may decide to relocate its intermediary HQ to another country where it will likely derive greater benefit from its ownership advantages.

Third, our study sheds additional light on the internal configuration and complexity of HQ systems. Recent studies have increasingly focused on intermediary HQs (e.g., Zhou, 2015; Nell et al., 2017; Schotter et al., 2017; Mahnke et al., 2012; Enright, 2005). Those units' special position within the MNC between the corporate HQ and the subsidiaries allows us to explore "the rich and complex reality of the firm" (Zhou, 2015, p. 290). We show that MNCs carefully manage the institutional distance between (1) the corporate HQ and the intermediary HQ, and (2) the intermediary HQ and supervised subsidiaries. On the one hand, MNCs seem to favour locations for their intermediary HQs that are institutionally distant from their home country to overcome their liability of foreignness and to better manage frontline subsidiaries. On the other hand, they try to reduce coordination and transaction costs by situating the intermediary HQs so that they are institutionally not too far from their home country. This represents a novel finding and extends our knowledge, showing how the location decision of parenting activities is influenced by institutional differences within the internal configuration of the MNC. 
The effect of change in institutional distance and geographical distance between frontline subsidiaries and intermediary HQs is not significant in our study. This insignificant effect might be explained by our measurement of the variables. We measure the average distance between intermediary HQs and subsidiaries. However, it is likely that some subsidiaries are more important than others in terms of size or growth. Hence, intermediary HQs are likely to attempt to reduce institutional distance to their most important subsidiaries, while they in turn accept larger distances to other subsidiaries. We were unable to capture such fine-grained measures. Nevertheless, our descriptive results (Table 4) show that intermediary HQs relocate to countries that are on average institutionally and geographically closer to their frontline subsidiaries.

\section{Implications for Managers and Policy Makers}

This study shows an increasing trend towards the relocation of intermediary HQs and offers several implications for executives and managers at the intermediary level so they may more comprehensively understand this phenomenon. First, our findings emphasize the need for HQ managers to consider the institutional quality of the host location instead of exclusively focusing on cost factors (such as taxation) when making a relocation decision for parenting units. Moving intermediary HQs to countries with high institutional quality may increase the parenting advantage of the HQs and may bring strategic benefits to the entire MNC. These advantages consist of possessing, interpreting and synthesizing local information in a better way to achieve competitive advantage, employing, and retaining appropriate staff, and operating smoothly at low transactionand coordination costs due to lower levels of uncertainty and formal institutional hazards.

Second, HQ managers should neither limit themselves to consider the institutional quality of the host location in absolute terms. The dynamism of formal institutions is also relevant. Unfavourable changes can dramatically reduce the abovementioned strategic benefits to the MNC. Thus, HQ managers should continuously monitor the institutional characteristics of their current host location and evaluate institutional change. 
Third, we offer to HQ managers a more fine-grained perspective from which to make an intermediary HQ relocation decision. Our findings highlight the complex nature of modern MNC structures and the importance of interdependence among different units within the organization. When considering an HQ relocation, managers should also bear in mind the relative institutional setup between the corporate and the intermediary HQ locations. Intermediary HQ managers should push for locations where cognitive frames, heuristics, and formal rules of the game are different from those found at the corporate HQ location; otherwise, the intermediary HQs' raison-d'être will fail.

Finally, our results offer implications to policy makers who are interested in attracting and retaining intermediary HQs. Policy makers should note that MNCs are more likely to choose good and stable institutional contexts for their HQs. They should also understand that the relocation of HQs overseas could have a negative impact on the economy and stability of their countries with a risk that professional service providers, such as bankers, accountants, and lawyers, may also move away. Therefore, governments should identify those HQ location factors on which they can have some control (e.g., governance effectiveness, economic stability, bureaucracy, corporate tax rates, and corruption) and continuously improve them to succeed in maintaining or gaining HQs in their countries.

\section{Limitations and Future Research}

Our study is not without limitations. First, much of the research in international business has focused on the role of formal institutions and their impact on firm decisions (e.g., Globerman \& Shapiro, 2003; Alvarez \& Marin, 2010). We also focus exclusively on formal institutions, as they are found to be more dynamic than informal institutions (Estrin et al., 2009). Therefore, we suggest that future research could investigate in greater depth the interplay between formal and informal institutions and their joint effect on HQ relocations (Sartor \& Beamish, 2014).

Second, our general understanding of the HQ relocation phenomenon is still limited. In our study, we exclusively investigate if a certain intermediary HQ is relocated. We do not explicitly 
identify to where the HQ has moved. While our descriptives in Table 4 allow for some insights into this matter, future research should address this 'where'-question so that we can develop a better understanding of the target countries of HQ relocations. Moreover, scholars have paid little attention to the HQ relocation process and the consequences of HQ relocations on the performance of MNCs (Nell et al., 2017). Future studies, both theoretically and empirically, could contribute to a more holistic understanding of this recent phenomenon.

Third, future research could add more complexity to our theoretical framework by adding a different research context. For example, current institutional events, such as Brexit or the current shift towards more protectionist policies, are increasing institutional instability with an increase in HQ relocation announcements. It might be interesting to investigate these effects on the relocation decision. It could also be highly promising to investigate the phenomenon of HQ relocations in emerging markets, as those countries offer more variance in terms of their national governance systems, their institutional heterogeneity, and their economic conditions.

Lastly, as suggested by Carney et al. (2018), the institutional configurations of countries have important effects on MNC performance and location decisions, and they "should be considered in addition to measures of institutional distance as a component of host country location (L) advantage" (Carney et al., 2018, pp. 2). Future studies could take this configuration perspective in investigating HQ relocations instead of considering only institutional quality and distance.

\section{Acknowledgements}

The authors acknowledge conversations with Jasper J. Hotho and fruitful guidance from the editor and three anonymous reviewers. 


\section{References}

Aglionby, J., \& Houlder, V. (2014, April 16). Starbucks relocates European headquarters to London. Financial Times. Retrieved from https://www.ft.com/

Alfoldi, E. A., McGaughey, S. L., \& Clegg, L. J. (2017). Firm Bosses or Helpful Neighbours? The Ambiguity and Co - Construction of MNE Regional Management Mandates. Journal of Management Studies, 54(8), 1170-1205.

Ali, A., \& Crain, W. M. (2001). Institutional distortions, economics freedom, and growth. Cato Journal, 21(3), 415-426.

Álvarez, I., \& Marín, R. (2010). Entry modes and national systems of innovation. Journal of International Management, 16(4), 340-353.

Ambos, T. C., \& Ambos, B. (2009). The impact of distance on knowledge transfer effectiveness in multinational corporations. Journal of International Management, 15(1), 1-14.

Baaij, M. G., \& Slangen, A. H. (2013). The role of headquarters-subsidiary geographic distance in strategic decisions by spatially disaggregated headquarters. Journal of International Business Studies, 44(9), 941-952.

Baaij, M. G., Mom, T. J., Van den Bosch, F. A., \& Volberda, H. W. (2015). Why do multinational corporations relocate core parts of their corporate headquarters abroad?. Long Range Planning, 48(1), 46-58.

Barner-Rasmussen, W., Piekkari, R. and Björkman, I. (2007). Mobility of headquarters in multinational corporations. European Journal of International Management, 1(3), 260-274.

Bartlett, C. A., \& Ghoshal, S. (1989). The transnational solution. Boston: Harvard Business School.

Bekaert, G., Harvey, C. R., Lundblad, C. T., \& Siegel, S. (2014). Political risk spreads. Journal of International Business Studies, 45(4), 471-493.

Belderbos, R., Du, H. S., \& Goerzen, A. (2017). Global cities, connectivity, and the location choice of MNC regional headquarters. Journal of Management Studies, 54(8), 1271-1302.

Benito, G., Lunnan, R. \& Tomassen, S. (2011). Distant encounters of the third kind: Multinational companies locating divisional headquarters abroad. Journal of Management Studies, 48(2), 373-394.

Berry, H., Guillén, M.F. \& Zhou, N. (2010). An institutional approach to cross-national distance. Journal of International Business Studies, 41(9), 1460-1480.

Bertrand, O., \& Mol, M. J. (2013). The antecedents and innovation effects of domestic and offshore R\&D outsourcing: The contingent impact of cognitive distance and absorptive capacity. Strategic Management Journal, 34(6), 751-760.

Beugelsdijk, S., Nell, P. C., \& Ambos, B. (2017). When do distance effects become empirically observable? An investigation in the context of headquarters value creation for subsidiaries. Journal of International Management, 23(3), 255-267.

Bevan, A., Estrin, S., \& Meyer, K. (2004). Foreign investment location and institutional development in transition economies. International Business Review, 13(1), 43-64. 
Birkinshaw, J., \& Hood, N. (1998). Multinational subsidiary evolution: Capability and charter change in foreign-owned subsidiary companies. Academy of Management Review, 23(4), 773-795.

Birkinshaw, J., Ambos, T. C., \& Bouquet, C. (2017). Boundary spanning activities of corporate HQ executives insights from a longitudinal study. Journal of Management Studies, 54(4), 422-454.

Birkinshaw, J., Braunerhjelm, P., Holm, U., \& Terjesen, S. (2006). Why do some multinational corporations relocate their headquarters overseas?. Strategic Management Journal, 27(7), 681-700.

Bouquet, C., \& Birkinshaw, J. (2008). Weight versus voice: How foreign subsidiaries gain attention from corporate headquarters. Academy of Management Journal, 51(3), 577-601.

Brenner, B., \& Ambos, B. (2013). A question of legitimacy? A dynamic perspective on multinational firm control. Organization Science, 24(3), 773-795.

Brouthers, K. D. (2002). Institutional, cultural and transaction cost influences on entry mode choice and performance. Journal of International Business Studies, 33(2), 203-221.

Cantwell, J., \& Santangelo, G. D. (1999). The frontier of international technology networks: sourcing abroad the most highly tacit capabilities. Information Economics and Policy, 11(1), 101-123.

Carney, M., Estrin, S., Liang, Z., \& Shapiro, D. (2018). National institutional systems, foreign ownership and firm performance: The case of understudied countries. Journal of World Business [this issue].

Chakravarty, D., Hsieh, Y. Y., Schotter, A. P., \& Beamish, P. W. (2017). Multinational enterprise regional management centres: Characteristics and performance. Journal of World Business, 52(2), 296-311.

Chan, C. M., \& Makino, S. (2007). Legitimacy and multi-level institutional environments: Implications for foreign subsidiary ownership structure. Journal of International Business Studies, 38(4), 621-638.

Collings, D. G., Morley, M. J., \& Gunnigle, P. (2008). Composing the top management team in the international subsidiary: Qualitative evidence on international staffing in US MNCs in the Republic of Ireland. Journal of World Business, 43(2), 197-212.

Contractor, F. J., Kumar, V., Kundu, S. K., \& Pedersen, T. (2010). Reconceptualizing the firm in a world of outsourcing and offshoring: The organizational and geographical relocation of high-value company functions. Journal of Management Studies, 47(8), 1417-1433.

Cuervo-Cazurra, A. (2006). Who cares about corruption?. Journal of International Business Studies, $37(6), 807-822$.

Decreton, B., Dellestrand, H., Kappen, P., \& Nell, P. C. (2017). Beyond Simple Configurations: The Dual Involvement of Divisional and Corporate Headquarters in Subsidiary Innovation Activities in Multibusiness Firms. MIR: Management International Review, 57(6), 855-878.

Decreton, B., Nell, P. C., \& Stea D. (2018). Headquarters involvement, socialization, and entrepreneurial behaviors in MNC subsidiaries. Long Range Planning.

Dellestrand, H. (2011). Subsidiary embeddedness as a determinant of divisional headquarters involvement in innovation transfer processes. Journal of International Management, 17(3), 229-242. 
Dellestrand, H., \& Kappen, P. (2012). The effects of spatial and contextual factors on headquarters resource allocation to MNE subsidiaries. Journal of International Business Studies, 43(3), 219-243.

Demirbag, M., \& Glaister, K. W. (2010). Factors determining offshore location choice for R\&D projects: A comparative study of developed and emerging regions. Journal of Management Studies, 47(8), 1534-1560.

Desai, M.A., 2009. The decentering of the global firm. The World Economy, 32(9), 1271-1290.

Di Maggio, P. \& Powell, W. (1983). The iron cage revisited: Institutional isomorphism and collective rationality in organizational fields. American Sociological Review. 48(2), 147-160.

Driffield, N., Mickiewicz, T., \& Temouri, Y. (2016). Ownership control of foreign affiliates: A property rights theory perspective. Journal of World Business, 51(6), 965-976.

Dunning, J. H. (1981). International production and the multinational enterprise. London: Allen \& Unwin.

Enright, M. J. (2005). The roles of regional management centers. MIR: Management International Review, 83-102.

Estrin, S., Baghdasaryan, D., \& Meyer, K. E. (2009). The impact of institutional and human resource distance on international entry strategies. Journal of Management Studies, 46(7), 1171-1196.

Fiaschi, D., Giuliani, E., \& Nieri, F. (2017). Overcoming the liability of origin by doing no-harm: Emerging country firms' social irresponsibility as they go global. Journal of World Business, 52(4), 546-563.

Floyd, S. W., \& Wooldridge, B. (1992). Middle management involvement in strategy and its association with strategic type: A research note. Strategic Management Journal, 13(S1), 153-167.

Forsgren, M., Holm, U., \& Johanson, J. (1995). Division headquarters go abroad: a step in the internationalization of the multinational corporation. Journal of Management Studies, 32(4), 475491.

Ghemawat, P. (2001). Distance still matters. Harvard Business Review, 79(8), 137-147.

Globerman, S., \& Shapiro, D. (2003). Governance infrastructure and US foreign direct investment. Journal of International Business Studies, 34(1), 19-39.

Goold, M., \& Campbell, A. (1991). Brief case: From corporate strategy to parenting advantage. Long Range Planning, 24(1), 115-117.

Goold, M., \& Campbell, A. (2002). Designing effective organizations: How to create structured networks. San Francisco: Jossey-Bass.

Hair, J. F., Black, W. C., Babin, B. J., Anderson, R. E. \& Tatham, R. L. (2006). Multivariate data analysis. New Jersey, Pearson Education.

Hart, O., \& Moore, J. (2005). On the design of hierarchies: coordination versus specialization. Journal of Political Economy, 113(4), 675-702. 
Hernández, V., \& Nieto, M. J. (2015). The effect of the magnitude and direction of institutional distance on the choice of international entry modes. Journal of World Business, 50(1), 122-132.

Hoenen, A. K., Nell, P. C., \& Ambos, B. (2014). MNE entrepreneurial capabilities at intermediary levels: the roles of external embeddedness and heterogeneous environments. Long Range Planning, 47(1-2), 76-86.

Holm, A. E., Decreton, B., Nell, P. C., \& Klopf, P. (2017). The Dynamic Response Process to Conflicting Institutional Demands in MNC Subsidiaries: An Inductive Study in the Sub-Saharan African E-Commerce Sector. Global Strategy Journal, 7(1), 104-124.

Holmes Jr, R. M., Miller, T., Hitt, M. A., \& Salmador, M. P. (2013). The interrelationships among informal institutions, formal institutions, and inward foreign direct investment. Journal of Management, 39(2), 531-566.

Jackson, G., \& Deeg, R. (2008). Comparing capitalisms: Understanding institutional diversity and its implications for international business. Journal of International Business Studies, 39(4), 540-561.

Kafouros, M., \& Aliyev, M. (2016). Institutional development and firm profitability in transition economies. Journal of World Business, 51(3), 369-378.

Kähäri, P., Saittakari, I., Piekkari, R., \& Barner-Rasmussen, W. (2017). Explaining mandate loss of regional headquarters: The difference between full and partial loss. Journal of Management Studies, 54(8), 1206-1240.

Kogut, B., \& Zander, U. (1992). Knowledge of the firm, combinative capabilities, and the replication of technology. Organization Science, 3(3), 383-397.

Kogut, B., \& Zander, U. (1995). Knowledge, market failure and the multinational enterprise: A reply. Journal of International Business Studies, 26(2), 417-426.

Kostova, T. \& Zaheer, S. (1999). Organizational legitimacy under conditions of complexity: the case of the multinational enterprise. Academy of Management Review, 24(1), 64-81.

Kostova, T., Nell, P. C., \& Hoenen, A. K. (2016). Understanding agency problems in headquarterssubsidiary relationships in multinational corporations: a contextualized model. Journal of Management, 3(1), 57-81.

Kumar, K.B., Rajan, R.G., \& Zingales, L. (2001). What determines firm size? CEPR Working paper, Center for Economic Policy Research, London.

Kwok, C. C., \& Tadesse, S. (2006). The MNC as an agent of change for host-country institutions: FDI and corruption. Journal of International Business Studies, 37(6), 767-785.

Laamanen, T., Simula, T. \& Torstila, S. (2012). Cross-border relocations of headquarters in Europe. Journal of International Business Studies, 43(2), 187-210.

Lehrer, M., \& Asakawa, K. (1999). Unbundling European operations: Regional management and corporate flexibility in American and Japanese MNCs. Journal of World Business, 34(3), 267-286.

Lewin, A. Y., Massini, S., \& Peeters, C. (2009). Why are companies offshoring innovation? The emerging global race for talent. Journal of International Business Studies, 40(6), 901-925. 
Lunnan, R., \& Zhao, Y. (2014). Regional headquarters in China: Role in MNE knowledge transfer. Asia Pacific Journal of Management, 31(2), 397-422.

Luxner, L. (2001). Procter \& Gamble decided to consolidate its back-office operations for all the Americas in one place. Latin CEO: Executive Strategies Americas (April) http://www.ticonet.co.cr/costa-rica/readings/0104.html.

Mahnke, V., Ambos, B., Nell, P. C., \& Hobdari, B. (2012). How do regional headquarters influence corporate decisions in networked MNCs?. Journal of International Management, 18(3), 293-301.

Manning, S., Massini, S., \& Lewin, A. Y. (2008). A Dynamic Perspective on Next-Generation Offshoring: The Global Sourcing of Science and Engineering Talent. The Academy of Management Perspectives, 35-54.

Meyer, J. \& Rowan, B. (1977). Institutionalized organizations: formal structure as myth and ceremony. American Journal of Sociology, 83(2), 340-363.

Meyer, K. E., \& Benito, G. R. (2016). Where do MNEs locate their headquarters? At home!. Global Strategy Journal, 6(2), 149-159.

Meyer, K. E., \& Peng, M. W. (2005). Probing theoretically into Central and Eastern Europe: Transactions, resources, and institutions. Journal of International Business Studies, 36(6), 600-621.

Meyer, K. E., Estrin, S., Bhaumik, S. K., \& Peng, M. W. (2009). Institutions, resources, and entry strategies in emerging economies. Strategic Management Journal, 30(1), 61-80.

Meyer, K. E., Mudambi, R., \& Narula, R. (2011). Multinational enterprises and local contexts: The opportunities and challenges of multiple embeddedness. Journal of Management Studies, 48(2), 235252.

Muellner, J., Klopf, P., \& Nell, P. C. (2017). Trojan Horses or Local Allies: Host-country National Managers in Developing Market Subsidiaries. Journal of International Management, 23(3), 306-325.

Nell, P. C., \& Ambos, B. (2013). Parenting advantage in the MNC: An embeddedness perspective on the value added by headquarters. Strategic Management Journal, 34(9), 1086-1103.

Nell, P. C., Ambos, B., \& Schlegelmilch, B. B. (2011). The benefits of hierarchy?-Exploring the effects of regional headquarters in multinational corporations. In Dynamics of Globalization: Location-Specific Advantages or Liabilities of Foreignness? (pp. 85-106). Emerald Group Publishing Limited.

Nell, P. C., Kappen, P., \& Laamanen, T. (2017). Reconceptualising hierarchies: The disaggregation and dispersion of headquarters in multinational corporations. Journal of Management Studies, 54(8), 1121-1143.

North, D. C. (1990). Institutions, institutional change and economic performance. Cambridge. Cambridge University Press.

North, D. C. (1991). Institutions. Journal of Economic Perspectives, 5(1), 97-112.

O'Brien, R. M. (2007). A caution regarding rules of thumb for variance inflation factors. Quality \& Quantity, 41(5), 673-690. 
Piekkari, R., Nell, P. C., \& Ghauri, P. N. (2010). Regional management as a system. MIR: Management International Review, 50(4), 513-532.

Poppo, L. (2003). The Visible Hands of Hierarchy within the M-Form: An Empirical Test of Corporate Parenting of Internal Product Exchanges. Journal of Management Studies, 40(2), 403-430.

Rodionova, Z. (2016, December 14). Brexit: 40\% of US firms with British offices are considering relocating to the EU. The Independent. Retrieved from https://www.independent.co.uk/

Rodriguez, P., Uhlenbruck, K., \& Eden, L. (2005). Government corruption and the entry strategies of multinationals. Academy of Management Review, 30(2), 383-396.

Rulison, L. (2015, November 18). GE moves renewable energy headquarters from Schenectady to Paris. Times Union. Retrieved from https://www.timesunion.com/

Sartor, M. A., \& Beamish, P. W. (2014). Offshoring innovation to emerging markets: Organizational control and informal institutional distance. Journal of International Business Studies, 45(9), 10721095.

Schotter, A. P., Mudambi, R., Doz, Y. L., \& Gaur, A. (2017). Boundary spanning in global organizations. Journal of Management Studies, 54(4), 403-421.

Slangen, A. H., \& Van Tulder, R. J. (2009). Cultural distance, political risk, or governance quality? Towards a more accurate conceptualization and measurement of external uncertainty in foreign entry mode research. International Business Review, 18(3), 276-291.

Slangen, A. H., Baaij, M., \& Valboni, R. (2017). Disaggregating the corporate headquarters: Investor reactions to inversion announcements by US firms. Journal of Management Studies, 54(8), 12411270.

Suchman, M. C. (1995). Managing legitimacy: Strategic and institutional approaches. Academy of Management Review, 20(3), 571-610.

Sullivan, D. (1994). Measuring the degree of internationalization of a firm. Journal of International Business Studies, 25(2), 325-342.

Thomas, M. (2009). What do the worldwide governance indicators measure? European Journal of Development Research, 22, 31-54.

Topham, G., \& Sweney, M. (2017, July 14). EasyJet to set up Austrian HQ to operate EU flights after Brexit. The Guardian. Retrieved from https://www.theguardian.com

UNCTAD (2003). World Investment Report: FDI Policies for Development: National and International Perspectives, New York and Geneva: United Nations Conference on Trade and Development.

Verbeke, A., \& Kenworthy, T. P. (2008). Multidivisional vs metanational governance of the multinational enterprise. Journal of International Business Studies, 39(6), 940-956.

Wolf, J., \& Egelhoff, W. G. (2002). A reexamination and extension of international strategy-structure theory. Strategic Management Journal, 23(2), 181-189. 
Wooldridge, B., \& Floyd, S. W. (1990). The strategy process, middle management involvement, and organizational performance. Strategic Management Journal, 11(3), 231-241.

Xu, D., \& Shenkar, O. (2002). Note: Institutional distance and the multinational enterprise. Academy of Management Review, 27(4), 608-618.

Zaheer, S. (1995). Overcoming the liability of foreignness. Academy of Management Journal, 38(2), 341-363.

Zhang, J., Zhou, C., \& Ebbers, H. (2011). Completion of Chinese overseas acquisitions: Institutional perspectives and evidence. International Business Review, 20(2), 226-238.

Zhao, J. H., Kim, S. H., \& Du, J. (2003). The impact of corruption and transparency on foreign direct investment: An empirical analysis. MIR: Management International Review, 41-62.

Zhou, Y. M. (2015). Supervising across borders: The case of multinational hierarchies. Organization Science, 26(1), 277-292. 
Table 1: Correlation Matrix and Summary Statistics.

\begin{tabular}{|c|c|c|c|c|c|c|c|c|c|c|c|c|c|c|c|c|}
\hline Variables & 1 & 2 & 3 & 4 & 5 & 6 & 7 & 8 & 9 & 10 & 11 & 12 & 13 & 14 & 15 & 16 \\
\hline 1 Decrease in Institutional Quality ${ }^{\mathrm{a}, \mathrm{b}}$ & 1.000 & & & & & & & & & & & & & & & \\
\hline 2 Increase in Avg. Inst. Distance to Subsidiaries ${ }^{a}$ & 0.397 & 1.000 & & & & & & & & & & & & & & \\
\hline 3 Increase in Inst. Distance to $\mathrm{CHQ}^{\mathrm{a}}$ & 0.307 & 0.328 & 1.000 & & & & & & & & & & & & & \\
\hline 4 Institutional Quality ${ }^{c}$ & -0.246 & -0.132 & -0.079 & 1.000 & & & & & & & & & & & & \\
\hline 5 Corporate Tax Rate ${ }^{a, c}$ & 0.235 & $\mathbf{0 . 1 5 8}$ & 0.096 & -0.239 & 1.000 & & & & & & & & & & & \\
\hline 6 Employment Rate ${ }^{\mathrm{a}, \mathrm{c}}$ & $-\mathbf{0 . 1 2 8}$ & -0.204 & -0.103 & 0.746 & -0.454 & 1.000 & & & & & & & & & & \\
\hline 7 GDP per Capita ${ }^{\mathrm{a}, \mathrm{c}}$ & -0.189 & -0.137 & -0.065 & 0.430 & -0.494 & 0.423 & 1.000 & & & & & & & & & \\
\hline 8 MNC Size Mac $^{\mathrm{a},}$ & -0.030 & -0.053 & -0.080 & -0.012 & -0.045 & 0.024 & 0.032 & 1.000 & & & & & & & & \\
\hline 9 Degree of Internationalization ${ }^{\mathrm{a}, \mathrm{c}}$ & -0.031 & -0.040 & -0.093 & 0.018 & 0.005 & 0.016 & 0.014 & 0.283 & 1.000 & & & & & & & \\
\hline 10M\&A Activity & -0.003 & -0.030 & -0.016 & -0.004 & 0.004 & -0.004 & -0.014 & -0.016 & -0.016 & 1.000 & & & & & & \\
\hline 11 Ownership Concentration ${ }^{c}$ & -0.013 & -0.003 & -0.024 & 0.011 & 0.013 & 0.001 & 0.001 & -0.044 & -0.045 & 0.002 & 1.000 & & & & & \\
\hline 12HQ Size ${ }^{\mathrm{a}, \mathrm{c}}$ & 0.018 & 0.008 & 0.019 & -0.021 & 0.004 & -0.015 & -0.031 & 0.164 & -0.295 & -0.004 & $\mathbf{0 . 0 3 8}$ & 1.000 & & & & \\
\hline $13 \mathrm{RHQ}$ & -0.013 & 0.006 & 0.009 & -0.001 & -0.009 & -0.009 & 0.012 & -0.018 & -0.028 & -0.026 & -0.010 & -0.010 & 1.000 & & & \\
\hline 14Trend Industry & -0.124 & -0.141 & -0.133 & -0.039 & -0.128 & 0.075 & 0.147 & 0.067 & 0.104 & 0.007 & 0.013 & 0.014 & 0.005 & 1.000 & & \\
\hline 15 Geographical Distance from $\mathrm{CHQ}^{\mathrm{a}}$ & 0.003 & 0.025 & 0.306 & -0.042 & 0.001 & -0.053 & 0.300 & -0.135 & -0.337 & -0.015 & -0.006 & 0.044 & 0.075 & -0.075 & 1.000 & \\
\hline 16 Avg. Geographical Distance from Subsidiaries ${ }^{a}$ & 0.014 & -0.008 & 0.021 & -0.045 & 0.104 & $-\mathbf{0 . 0 3 8}$ & -0.112 & -0.008 & -0.017 & 0.003 & 0.008 & -0.001 & -0.054 & -0.009 & 0.015 & 1.000 \\
\hline Mean & 0.058 & 0.049 & 0.041 & 4.492 & 3.319 & 4.239 & 10.547 & 8.169 & 0.202 & 0.168 & 0.606 & 4.884 & 0.513 & 10.631 & 4.378 & 7.103 \\
\hline Std. Dev. & 0.106 & 0.093 & 0.104 & 0.492 & 0.299 & 0.078 & 0.141 & 1.249 & 0.103 & 0.374 & 0.489 & 1.051 & 0.500 & 5.287 & 3.445 & 0.664 \\
\hline Min & 0 & 0 & 0 & 2.733 & 0 & 3.987 & 9.683 & 0.693 & 0.001 & 0 & 0 & 0 & 0 & 0 & 0 & 0 \\
\hline Max & 0.758 & 0.798 & 0.903 & 5.333 & 3.761 & 4.388 & 11.423 & 13.348 & 0.622 & 1 & 1 & 10.103 & 1 & 21 & 9.822 & 9.338 \\
\hline
\end{tabular}

Notes: $\mathrm{N}=3,467$. Correlations in bold are statistically significant at $\mathrm{p}<0.05$. In the regression model, we also control for industries based on the first digit of the SIC code classification. Abbreviations: Avg. = Average; Inst. = Institutional.

a Log value.

b Absolute value.

c Lagged by one year. 
Table 2: Variable Definitions.

\begin{tabular}{|c|c|c|}
\hline Variables & Definition & Source \\
\hline Relocation & $\begin{array}{l}\text { Equals } 1 \text { if the HQ got relocated in the specific } \\
\text { year }(1,0)\end{array}$ & $\begin{array}{l}\text { LexisNexis, } \\
\text { Factiva }\end{array}$ \\
\hline \multicolumn{3}{|l|}{ Main independent variables } \\
\hline Decrease in Institutional Quality ${ }^{\mathrm{a}, \mathrm{b}}$ & $\begin{array}{l}\text { Absolute deterioration of institutional quality in } \\
\text { the intermediary HQ country over a three-year } \\
\text { period (five-year period for robustness test) }\end{array}$ & ICRG \\
\hline $\begin{array}{l}\text { Increase in Avg. Inst. Distance to } \\
\text { Subsidiaries }^{\mathrm{a}}\end{array}$ & $\begin{array}{l}\text { Increase in average institutional distance between } \\
\text { intermediary HQ country and subsidiary countries } \\
\text { over a three-year period (five-year period for } \\
\text { robustness test) }\end{array}$ & ICRG \\
\hline Increase in Inst. Distance to $\mathrm{CHQ}^{\mathrm{a}}$ & $\begin{array}{l}\text { Increase in institutional distance between CHQ } \\
\text { country and intermediary HQ country over a three- } \\
\text { year period (five-year period for robustness test) }\end{array}$ & ICRG \\
\hline \multicolumn{3}{|l|}{ Country-level variables } \\
\hline Institutional Quality ${ }^{\mathrm{c}}$ & $\begin{array}{l}\text { Level of institutional quality in intermediary HQ } \\
\text { country one year before relocation }\end{array}$ & ICRG \\
\hline Corporate Tax Rate ${ }^{\mathrm{a}, \mathrm{c}}$ & $\begin{array}{l}\log \text { (corporate tax rate in intermediary HQ country } \\
\text { before relocation) }\end{array}$ & OECD \\
\hline Employment Rate ${ }^{\mathrm{a}, \mathrm{c}}$ & $\begin{array}{l}\log (\text { employment rate in intermediary HQ country } \\
\text { before relocation) }\end{array}$ & OECD \\
\hline GDP per Capita ${ }^{\mathrm{a}, \mathrm{c}}$ & $\begin{array}{l}\log \text { (GDP per Capita in intermediary HQ country } \\
\text { before relocation) }\end{array}$ & OECD \\
\hline \multicolumn{3}{|l|}{ MNC parent-level variables } \\
\hline MNC Size ${ }^{\mathrm{a}, \mathrm{c}}$ & $\log$ (number of MNC employees) & Orbis \\
\hline Degree of Internationalization ${ }^{\mathrm{a}, \mathrm{c}}$ & $\log ($ foreign $\mathrm{MNC}$ revenue/total MNC revenue) & Orbis \\
\hline M\&A Activity & $\begin{array}{l}\text { Equals } 1 \text { if MNC was involved in M\&A activity in } \\
\text { the last three years }(1,0)\end{array}$ & Osiris \\
\hline Ownership Concentration $^{c}$ & $\begin{array}{l}\text { Equals } 1 \text { if MNC ownership is concentrated, i.e., } \\
\text { one shareholder has more than } 20 \% \text { of all shares } \\
(1,0)\end{array}$ & Orbis \\
\hline Industry & $\begin{array}{l}\text { First digit of the SIC code classification (from } 1 \text { to } \\
\text { 8) }\end{array}$ & Orbis \\
\hline \multicolumn{3}{|l|}{ HQ-level variables } \\
\hline HQ Size ${ }^{\mathrm{a}, \mathrm{c}}$ & $\log$ (number of HQ employees) & Orbis \\
\hline RHQ & Equals 1 if the HQ is an RHQ $(0=\mathrm{DHQ})$ & Orbis \\
\hline Trend Industry & $\begin{array}{l}\text { Accumulated HQ relocations in the same industry } \\
\text { in the years before the observation }\end{array}$ & - \\
\hline Geographical Distance from $\mathrm{CHQ}^{\mathrm{a}}$ & $\begin{array}{l}\log \text { (geographical distance between intermediary } \\
\text { HQ country and CHQ country) }\end{array}$ & $\begin{array}{l}\text { Berry et al. } \\
(2010)\end{array}$ \\
\hline $\begin{array}{l}\text { Avg. Geographical Distance from } \\
\text { Subsidiaries }^{\mathrm{a}}\end{array}$ & $\begin{array}{l}\log \text { (average geographical distance between } \\
\text { intermediary HQ country and subsidiary countries) }\end{array}$ & $\begin{array}{l}\text { Berry et al. } \\
(2010)\end{array}$ \\
\hline
\end{tabular}

Notes:

${ }^{\mathrm{a}} \log$ value.

b Absolute value.

${ }^{\mathrm{c}}$ Lagged by one year. 
Table 3: Comparison between non-relocated units and relocated units.

\begin{tabular}{|c|c|c|c|}
\hline Variables & $\begin{array}{l}\text { Non-relocated } \\
\text { Units } \\
\text { Mean }\end{array}$ & Relocated Units & $\begin{array}{l}\text { t-test for } \\
\text { differences in } \\
\text { means }\end{array}$ \\
\hline \multicolumn{4}{|l|}{ Institutional variables } \\
\hline Decrease in Institutional Quality ${ }^{b}$ & 0.065 & 0.079 & -1.231 \\
\hline $\begin{array}{l}\text { Increase in Avg. Inst. Distance to } \\
\text { Subsidiaries }\end{array}$ & 0.056 & 0.050 & 0.547 \\
\hline Increase in Inst. Distance to CHQ & 0.048 & 0.054 & -0.540 \\
\hline Institutional Quality ${ }^{\mathrm{c}}$ & 4.490 & 4.545 & -1.351 \\
\hline $\begin{array}{l}\text { Institutional Distance intermediary HQ } \\
\text { - Subsidiaries }{ }^{\mathrm{c}}\end{array}$ & 0.185 & 0.264 & -1.577 \\
\hline $\begin{array}{l}\text { Institutional Distance CHQ - } \\
\text { intermediary } \mathrm{HQ}^{\mathrm{c}}\end{array}$ & -0.021 & -0.194 & $3.464 * * *$ \\
\hline \multicolumn{4}{|l|}{ Country-level variables } \\
\hline Corporate Tax Rate ${ }^{c}$ & 27.700 & 27.351 & 0.621 \\
\hline Employment Rate & 68.503 & 69.762 & $-2.875 * * *$ \\
\hline GDP per Capita ${ }^{\mathrm{c}}$ & 38,400 & 40,364 & $-3.650 * * *$ \\
\hline \multicolumn{4}{|l|}{ MNC parent-level variables } \\
\hline MNC Size $^{\mathrm{c}}$ & 8,503 & 64,557 & $-19.360 * * *$ \\
\hline Degree of Internationalization $^{c}$ & 0.227 & 0.309 & $-7.446 * * *$ \\
\hline M\&A Activity & 0.172 & 0.084 & $2.853 * * *$ \\
\hline Ownership Concentration $^{c}$ & 0.620 & 0.318 & $7.545 * * *$ \\
\hline \multicolumn{4}{|l|}{ Industry } \\
\hline 1 & 0.088 & 0.019 & $2.971 * * *$ \\
\hline 2 & 0.114 & 0.208 & $-3.510 * * *$ \\
\hline 3 & 0.168 & 0.331 & $-5.246 * * *$ \\
\hline 4 & 0.113 & 0.071 & 1.601 \\
\hline 5 & 0.176 & 0.078 & $3.158 * * *$ \\
\hline 6 & 0.236 & 0.097 & $4.012 * * *$ \\
\hline 7 & 0.058 & 0.136 & $-.3993 * * *$ \\
\hline 8 & 0.048 & 0.058 & -0.609 \\
\hline \multicolumn{4}{|l|}{$H Q$-level variables } \\
\hline HQ Size & 218.734 & 466.065 & $-5.441 * * *$ \\
\hline $\begin{array}{l}\text { Number of subsidiaries under the } \\
\text { control of the HQ }\end{array}$ & 4.733 & 5.300 & $-4.164 * * *$ \\
\hline RHQ & 0.508 & 0.630 & $-2.968 * * *$ \\
\hline Trend & 10.648 & 10.266 & 0.876 \\
\hline Geographical Distance from CHQ & 777.930 & $5,131.864$ & $-38.013 * * *$ \\
\hline $\begin{array}{l}\text { Avg. Geographical Distance from } \\
\text { Subsidiaries }\end{array}$ & $1,507.485$ & $1,835.800$ & $-3.319 * * *$ \\
\hline
\end{tabular}

Notes: Table 3 shows the means for each variable in the group of non-relocated units $(\mathrm{N}=3,313)$ and in the group of relocated units $(\mathrm{N}=154)$, as well as the $\mathrm{t}$-statistics for the difference in means. $* * *$ and $* * *$ denote significance at the $10 \%, 5 \%$ and $1 \%$ level.

${ }^{a}$ Log value.

${ }^{\mathrm{b}}$ Absolute value.

${ }^{\mathrm{c}}$ Lagged by one year. 
Table 4: Comparison of key variables for relocating intermediary HQs before and after relocation.

\begin{tabular}{|c|c|c|}
\hline Variables & $\begin{array}{l}\text { Mean value before } \\
\text { relocation }\end{array}$ & $\begin{array}{l}\text { Mean value after } \\
\text { relocation }\end{array}$ \\
\hline \multicolumn{3}{|l|}{ Institutional variables } \\
\hline Institutional Quality ${ }^{\mathrm{c}}$ & 4.545 & 4.466 \\
\hline Change in Institutional Quality & -0.052 & -0.025 \\
\hline Avg. Institutional Distance intermediary HQ - Subsidiaries ${ }^{\mathrm{b}, \mathrm{c}}$ & 0.264 & 0.185 \\
\hline Institutional Distance CHQ - intermediary $\mathrm{HQ}^{\mathrm{b}, \mathrm{c}}$ & -0.194 & -0.115 \\
\hline \multicolumn{3}{|l|}{ Country-level variables } \\
\hline Corporate Tax Rate ${ }^{\mathrm{c}}$ & 27.351 & 20.675 \\
\hline Employment Rate ${ }^{\mathrm{c}}$ & 69.762 & 66.791 \\
\hline GDP per Capita ${ }^{\mathrm{c}}$ & 40,364 & 42,948 \\
\hline \multicolumn{3}{|l|}{ HQ-level variables } \\
\hline HQ Size ${ }^{c}$ & 466.065 & 270.740 \\
\hline Geographical Distance from CHQ & $5,131.864$ & $6,489.662$ \\
\hline Avg. Geographical Distance from Subsidiaries & $1,835.800$ & $1,477.908$ \\
\hline
\end{tabular}

Notes: Table 4 shows the means for each variable before and after the HQ relocation $(\mathrm{N}=154)$.

${ }^{\text {a }}$ Log value.

${ }^{\mathrm{b}}$ Absolute value.

${ }^{\mathrm{c}}$ Lagged by one year. 
Table 5: Logistic regression of decision to relocate intermediary HQ units.

\begin{tabular}{|c|c|c|c|c|}
\hline & $\frac{\text { Model 1 }}{\text { Logit }}$ & $\frac{\text { Model } 2}{\text { Logit }}$ & $\frac{\text { Model } 3}{\text { Robust cluster }}$ & $\begin{array}{c}\text { Model } 4 \\
\begin{array}{c}\text { Robust year } \\
\text { cluster }\end{array}\end{array}$ \\
\hline Decrease in Institutional Quality $(\mathrm{H} 1)^{\mathrm{a}, \mathrm{b}}$ & & $\begin{array}{l}2.729 * * \\
(1.091)\end{array}$ & $\begin{array}{l}2.729 * * \\
(1.198)\end{array}$ & $\begin{array}{l}2.729 * * \\
(1.075)\end{array}$ \\
\hline Increase in Avg. Institutional Distance & & 0.332 & 0.332 & 0.332 \\
\hline to Subsidiaries $(\mathrm{H} 2)^{\mathrm{a}, \mathrm{b}}$ & & $(1.239)$ & $(1.305)$ & $(1.397)$ \\
\hline Increase in Institutional Distance to & & $-2.366 * *$ & $-2.366 * *$ & $-2.366 * * *$ \\
\hline $\mathrm{CHQ}(\mathrm{H} 3)^{\mathrm{a}, \mathrm{b}}$ & & $(1.169)$ & $(1.020)$ & $(0.904)$ \\
\hline Institutional Quality ${ }^{\mathrm{c}}$ & $\begin{array}{l}-0.717 * * \\
(0.323)\end{array}$ & $\begin{array}{l}-0.444 \\
(0.346)\end{array}$ & $\begin{array}{l}-0.444 \\
(0.373)\end{array}$ & $\begin{array}{l}-0.444 \\
(0.337)\end{array}$ \\
\hline Corporate Tax Rate ${ }^{\mathrm{a}, \mathrm{c}}$ & $\begin{array}{l}0.728 * \\
(0.381)\end{array}$ & $\begin{array}{l}0.525 \\
(0.405)\end{array}$ & $\begin{array}{l}0.525 \\
(0.444)\end{array}$ & $\begin{array}{l}0.525 \\
(0.341)\end{array}$ \\
\hline Employment Rate ${ }^{\mathrm{a}, \mathrm{c}}$ & $\begin{array}{l}6.871 * * * \\
(2.241)\end{array}$ & $\begin{array}{l}5.636 * * \\
(2.291)\end{array}$ & $\begin{array}{l}5.636 * * \\
(2.422)\end{array}$ & $\begin{array}{l}5.636 * * * \\
(1.568)\end{array}$ \\
\hline GDP per Capita ${ }^{\mathrm{a}, \mathrm{c}}$ & $\begin{array}{l}1.777 * * \\
(0.752)\end{array}$ & $\begin{array}{l}1.789 * * \\
(0.758)\end{array}$ & $\begin{array}{l}1.789 * * \\
(0.768)\end{array}$ & $\begin{array}{l}1.789 * * * \\
(0.620)\end{array}$ \\
\hline MNC Size ${ }^{\mathrm{a}, \mathrm{c}}$ & $\begin{array}{l}0.934 * * * \\
(0.073)\end{array}$ & $\begin{array}{l}0.950 * * * \\
(0.075)\end{array}$ & $\begin{array}{l}0.950 * * * \\
(0.089)\end{array}$ & $\begin{array}{l}0.950 * * * \\
(0.084)\end{array}$ \\
\hline Degree of Internationalization ${ }^{\mathrm{a}, \mathrm{c}}$ & $\begin{array}{l}0.012 \\
(0.853)\end{array}$ & $\begin{array}{l}0.107 \\
(0.856)\end{array}$ & $\begin{array}{l}0.107 \\
(1.163)\end{array}$ & $\begin{array}{l}0.107 \\
(1.163)\end{array}$ \\
\hline M\&A Activity & $\begin{array}{l}-0.778 * * \\
(0.339)\end{array}$ & $\begin{array}{l}-0.777 * * \\
(0.341)\end{array}$ & $\begin{array}{l}-0.777 * * \\
(0.352)\end{array}$ & $\begin{array}{l}-0.777 * * \\
(0.308)\end{array}$ \\
\hline Ownership Concentration $^{c}$ & $\begin{array}{l}-0.997 * * * \\
(0.207)\end{array}$ & $\begin{array}{l}-0.996 * * * \\
(0.207)\end{array}$ & $\begin{array}{l}-0.996 * * * \\
(0.201)\end{array}$ & $\begin{array}{l}-0.996 * * * \\
(0.203)\end{array}$ \\
\hline Industry & & & & \\
\hline 2 & $\begin{array}{l}2.272 * * * \\
(0.682)\end{array}$ & $\begin{array}{l}2.236 * * * \\
(0.673)\end{array}$ & $\begin{array}{l}2.236 * * * \\
(0.606)\end{array}$ & $\begin{array}{l}2.236 * * * \\
(0.613)\end{array}$ \\
\hline 3 & $\begin{array}{l}2.078 * * * \\
(0.668)\end{array}$ & $\begin{array}{l}2.059 * * * \\
(0.659)\end{array}$ & $\begin{array}{l}2.059 * * * \\
(0.596)\end{array}$ & $\begin{array}{l}2.059 * * * \\
(0.648)\end{array}$ \\
\hline 4 & $\begin{array}{l}0.944 \\
(0.733)\end{array}$ & $\begin{array}{l}0.900 \\
(0.726)\end{array}$ & $\begin{array}{l}0.900 \\
(0.662)\end{array}$ & $\begin{array}{l}0.900 \\
(0.597)\end{array}$ \\
\hline 5 & $\begin{array}{l}0.748 \\
(0.719)\end{array}$ & $\begin{array}{l}0.706 \\
(0.709)\end{array}$ & $\begin{array}{l}0.706 \\
(0.660)\end{array}$ & $\begin{array}{l}0.706 \\
(0.644)\end{array}$ \\
\hline 6 & $\begin{array}{l}1.010 \\
(0.699)\end{array}$ & $\begin{array}{l}0.953 \\
(0.691)\end{array}$ & $\begin{array}{l}0.953 \\
(0.647)\end{array}$ & $\begin{array}{l}0.953 \\
(0.697)\end{array}$ \\
\hline 7 & $\begin{array}{l}2.560 * * * \\
(0.710)\end{array}$ & $\begin{array}{l}2.503 * * * \\
(0.701)\end{array}$ & $\begin{array}{l}2.503 * * * \\
(0.618)\end{array}$ & $\begin{array}{l}2.503 * * * \\
(0.630)\end{array}$ \\
\hline 8 & $\begin{array}{l}1.842 * * \\
(0.762)\end{array}$ & $\begin{array}{l}1.853 * * \\
(0.755)\end{array}$ & $\begin{array}{l}1.853 * * * \\
(0.699)\end{array}$ & $\begin{array}{l}1.853 * * * \\
(0.712)\end{array}$ \\
\hline HQ Size ${ }^{a, c}$ & $\begin{array}{l}-0.578 * * * \\
(0.082)\end{array}$ & $\begin{array}{l}-0.588 * * * \\
(0.082)\end{array}$ & $\begin{array}{l}-0.588 * * * \\
(0.105)\end{array}$ & $\begin{array}{l}-0.588 * * * \\
(0.107)\end{array}$ \\
\hline RHQ & $\begin{array}{l}0.270 \\
(0.207)\end{array}$ & $\begin{array}{l}0.253 \\
(0.208)\end{array}$ & $\begin{array}{l}0.253 \\
(0.184)\end{array}$ & $\begin{array}{l}0.253 \\
(0.194)\end{array}$ \\
\hline Trend Industry & $\begin{array}{l}-0.042 * * \\
(0.021)\end{array}$ & $\begin{array}{l}-0.038^{*} \\
(0.021)\end{array}$ & $\begin{array}{l}-0.038 \\
(0.024)\end{array}$ & $\begin{array}{l}-0.038 \\
(0.033)\end{array}$ \\
\hline Geographical Distance from $\mathrm{CHQ}^{\mathrm{a}}$ & $\begin{array}{l}0.297 * * * \\
(0.035)\end{array}$ & $\begin{array}{l}0.320 * * * \\
(0.037)\end{array}$ & $\begin{array}{l}0.320 * * * \\
(0.043)\end{array}$ & $\begin{array}{l}0.320 * * * \\
(0.040)\end{array}$ \\
\hline $\begin{array}{l}\text { Avg. Geographical Distance from } \\
\text { Subsidiaries }^{\mathrm{a}}\end{array}$ & $\begin{array}{l}0.256^{*} \\
(0.154)\end{array}$ & $\begin{array}{l}0.271 * \\
(0.155)\end{array}$ & $\begin{array}{l}0.271 \\
(0.172)\end{array}$ & $\begin{array}{l}0.271 * \\
(0.143)\end{array}$ \\
\hline Constant & $\begin{array}{l}-59.829 * * * \\
(13.196)\end{array}$ & $\begin{array}{l}-55.705 * * * \\
(13.612)\end{array}$ & $\begin{array}{l}-55.705 * * * \\
(16.056)\end{array}$ & $\begin{array}{l}-55.705 * * * \\
(12.096)\end{array}$ \\
\hline Nr. of Observations & 3,467 & 3,467 & 3,467 & 3,467 \\
\hline Pseudo $\mathrm{R}^{2}$ & 0.382 & 0.389 & 0.389 & 0.389 \\
\hline
\end{tabular}

Notes: $* * *$ and $* * *$ denote significance at the $10 \%, 5 \%$ and $1 \%$ level. Standard errors in parenthesis.

${ }^{\mathrm{a}}$ Log value. ${ }^{\mathrm{b}}$ Absolute value. ${ }^{\mathrm{c}}$ Lagged by one year. 